\title{
DETERMINANTS OF CASH WAQF CONTRIBUTION IN KLANG VALLEY AND SELANGOR: A SEM APPROACH
}

\author{
Muhammad Rizky Prima Sakti ${ }^{1}$ \\ Hassanudin bin Mohd Thas Thaker ${ }^{2}$ \\ Abdul Qoyum ${ }^{3}$ \\ Ibnu Qizam ${ }^{4}$
}

\begin{abstract}
Cash waqf is becoming one of the popular Islamic financial instruments which not only focus on the religiosity but also has significant impact to the ummah development. This waqf scheme does not require richness in wealth, yet everybody in the society can contribute to cash waqf. The importance of cash waqf is getting popular as it has benefited in many ways, for example it can be used to develop assets and abandoned land for business and agricultural purposes. In addition, cash waqf also can be utilized to help institutions who are facing financial problem or liquidity issues. Nonetheless, rarely we found in the literature that empirically examines the cash waqf determinants and contributions. This paper is one of the few empirical studies that investigate the determinants towards the contribution of cash waqf in Malaysia. The purpose of this paper is to investigate the main factors that influence people towards the contribution of cash waqf instruments, special reference to the Klang Valley and Selangor. This paper employs structural equation modeling (SEM) to verify the determinants of cash waqf contribution. In doing so, we use primary data by distributing self-administrated questionnaire constituting a sample of 114 respondents from Klang Valley and Selangor. Our empirical results reveal that the main factors that driven people towards the contribution of cash waqf products are attitude and social influences, however interestingly religion obligation is not influence the contribution of cash waqf.
\end{abstract}

Keywords: Cash waqf, Malaysia, Structural Equation Modeling (SEM)

JEL Classification: $\mathrm{H} 8$

Received: October 3, 2015; Revised: August 24, 2016; Accepted: August 26, 2016

1 Researcher, ISEFID (Islamic Economics Forum for Indonesian Development), Kuala Lumpur, Malaysia. Email: rizky_islamicfinance@yahoo.com [Corresponding author]

2 Lecturer. HELP University, Kuala Lumpur, Malaysia. Email : hans5587@hotmail.com

3 Lecturer. UIN Sunan Kalijaga, Yogyakarta, Indonesia. Email: agus.qoyum@yahoo.com

4 Lecturer. UIN Sunan Kalijaga, Yogyakarta, Indonesia. Email: qzami68@gmail.com 
112 Determinants of Cash Waqf Contribution in Klang Valley and Selangor: A SEM Approach

\section{INTRODUCTION}

In the realm of Islamic perspective, the instruments for wealth distribution can be categorized into two, i.e. obligatory and nonobligatory. The former tools are zakat, khums, kaharaj, and jizyah, while the latter including waqf, wasiyah, sadaqah, and qard hassan. These are initially voluntary giving to get the reward and blessing from Allah The Most High. The term of waqf (endowment) literally means to stop, to prevent, and to restrain. Waqf literally means tying up property for some pious object recognised by shariah to gain divine pleasure in such a way that the asl (corpus) remains intact and only its usufruct is spent on the name object Mohsin (2009) defined waqf as the holding and preservation of certain philanthropy with the intention of prohibiting of any use or disposition of the property utside the specific purposes to which the property is dedicated, in such way that it cannot be bequeathed or sold. There are four important criterias to contirbute on waqf; (1) the intention; (2) the donor, (3) the property or any tangible or intangible asset given as waqf, (4) the beneficiary (Anwar, Meera, \& Saleem, 2014).

Historically speaking, the waqf institution achieved the prosperous era during the Ottoman Caliph. During this time, the waqf institutions had developed in terms of size and services between municipal services, education, health, and religion. More so, as many 35,000 awqaf institutions (including property and cash) had been established during the Caliph era. In Malaysia, the development of waqf can be traced bak since the 15th century during the era of Malacca Sultanate. In that time, waqf was subejcted to popular practiced among Muslim people, such as waqf in the form of mosque and madrasah.

The cash waqf is special type of endowment which differed from the ordinary waqf in that its original capital is purely or partially of cash (Cizakca, 2000). Cash waqf can be defined as the confinement of an amount of money or cash from the founder and the dedication of its usufruct, according to founder's condition in perpetuity to the welfare of society. The current practices of cash waqf in Malaysia through shares waqf by which the State Islamic Religious Council (SIRC) offers shares waqf with certain rates for the public. The society will purchase these shares in cash and the 
money/cash immediately transferred to State Islamic Religious Council. Subsequently, this council will collect all cash in the endowment fund for the creation of waqf properties. Through this process, every society who does not have a property or not being able to get property for waqf, still can perform collective waqf. Moreover, the mechanism of cash waqf scheme had implemented by several state religious council in Malaysia. There are six States Religious Council in Malaysia that offered the cash waqf schemes. Table 1 below depicts the cash waqf scheme in several states in Malaysia.

Table 1.

Cash Waqf Scheme in Several Malaysian States

\begin{tabular}{lc}
\hline States & Minimum Waqf Price (RM) \\
\hline Penang Waqf Fund Scheme & 5 \\
Selangor WaqfShare & 10 \\
Pahang WaqfShare & 10 \\
Johor WaqfShare & 10 \\
Terengganu WaqfShare & 10 \\
Malacca WaqfShare & 10 \\
\hline
\end{tabular}

Source: Perbadanan Waqf Selangor, MAIS (2013)

Typically, waqf management of Selangor is managed by "Selangor Waqf Corporation/ Perbadanan Waqf Selangor (PWS)" which basically as sub-institution of Majlis Agama Islam Selangor (MAIS). The institution of PWS was established in 2011 with the purpose of to cultivate the waqf activities among the public for building the economic of ummah and increase the value added of waqf properties. Subsequently, There are three types of cash waqf schemes managed by PWS: (1) Selangor Waqf Share scheme, (2) Infaq scheme, and (3) Sahabat Corporate scheme. In addition to that, Selangor waqf share is an instrument of cash waqf at which the society (public) purchases the shares at certain rates offered by MAIS and declared its share as waqf in perpetuity because of Allah (SWT) to promote the socio-economic welfare of Muslim society. The participation to Selangor waqf share is open to all Muslim society and Muslim owned companies without any limit. Figure below shows the development of share waqf in Selangor. 


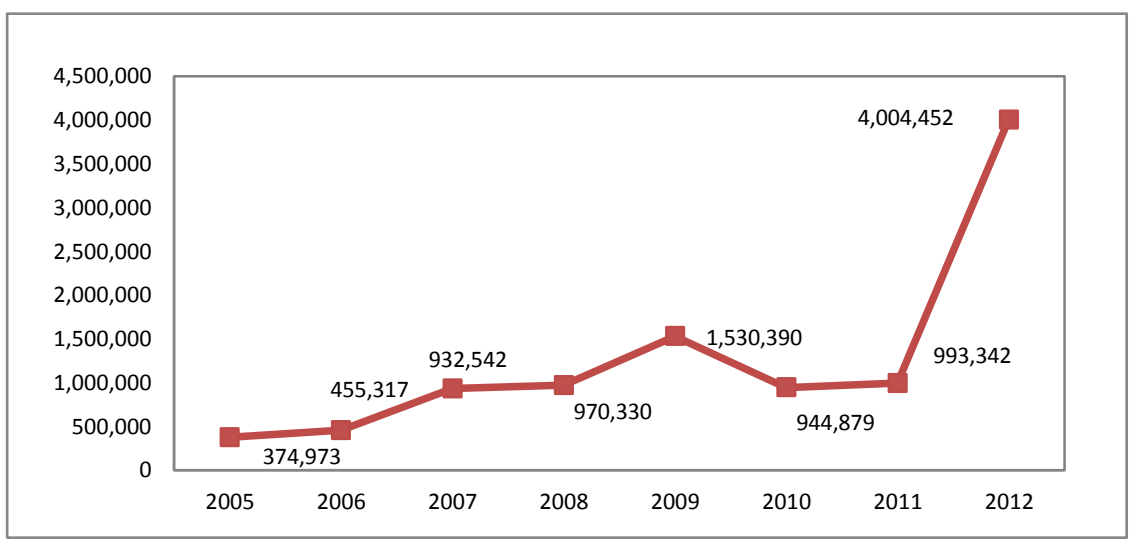

Figure 1.

Selangor Waqf Share (RM)

Source: Perbadanan Waqf Selangor, MAIS (2013)

As the matter of fact that cash waqf instruments show an increasing trend among Malaysian, and its can contribute to socioeconomic welfare of society. This promising trend in the waqf instruments therefore attracted the interest of practitioners and researchers to embark on research in different horizon. Based on this backdrop, this study attempt to investigate the determinants that influences public to involve in cash waqf instruments. Specifically, ours study try to provide answers of the following research questions: What are the factors which people consider important to participate on cash waqf? The remaining of this paper is organized as followed: chapter two will discuss on literature review, chapter three will elaborate on research methodology, chapter four will discuss the empirical findings and discussion, and chapter five is conclusion.

\section{LITERATURE REVIEW}

\subsection{Overview of Cash Waqf}

Cash waqf can be defined as the confinement of an amount of money or cash from the founder and the dedication of its usufruct, according to founder's condition in perpetuity to the welfare of 
society. Cash waqf can be invested in mudharabah and the revenue generated from this cash waqf enables investment undertakings in various activities for the purposes of charity. Cash waqf is another form of waqf than physical assets such as land and buildings. In cash waqf the money or cash is invested and the proceeds are used for the social benefits.

From Hanafi school of thought, Imam Abu Hanifah agreed that all movable properties subject to waqf including the waqf of dirham and dinnar, for instance waqf al-nuqud (cash waqf). In line with that opinion, Imam Zufar stated that jewellery could also be subjected to waqf. Similarly, both Imam Muhammad and alSarakhsi agreed that movable items as the subject matter for waqf. Imam Malik also agreed that both movable and immovable properties considered as subject matter for waqf even if it is cash waqf. In addition, Imam Shafii and Hanbali argued on the validity of both immovable and movable properties as a subject matter of waqf. In recent time, World Fiqh Council (Majma' al-Fiqh) issued fatwa on this matter had also agreed on the creation of cash waqf.

Furthermore, Shafi'i approved the creation of waqf from non-Muslim even if it is for the purpose of a mosque. His opinion based on hadith: "The Prophet (pbuh) said Allah will not oppress Muslim for their good deeds, as they will be rewarded in this world and in the hereafter. But for non-Muslims they will be rewarded for all their good deeds only in this world". Thus, based on the hadith, it enables the non-Muslim to participate in cash waqf creation.

Islamic jurists had agreed on conditions regarding the validity of cash waqf, the conditions necessary for the validity of cash waqf can be written as follows:

1) The founder of cash waqf must be in full possession of his physical and mental capabilities, adult, and free man/women. He must be capable of transferring the money/cash from his ownership to the ownership of Allah (SWT).

2) The founder has the right to appoint his/her trustee.

3) The founder in his /her waqfiah (waqf deed) should specify the beneficiaries. The beneficiaries could be their relatives, poor and needy people, or any charitable purpose for instance building a mosque, school, or hospitals. 
Moreover, Islamic jurists further argued that the validity of cash waqf is depend on the purpose of its money/cash itself. If the money/cash is solely used for the purpose of medium of exchange for goods/products, thus, this money cannot be approved as the subject matter for cash waqf. The logic is that because the money itself will be runs out after immediately exchange for goods and services (Al-Zuhaili, 1989). Conversely, if the purpose of the money/cash used as the subject for cash waqf does not mislead the cash become depleted, thus, the money/cash can be subject to cash waqf (Sayin, 1994).

According to Baharuddin (2011), the condition for money/cash that might be used as cash waqf is that:

1) The cash/money that declared for cash waqf should be exchanged with an asset such as property, stocks, or capital at which only its usufruct, dividend, or revenues that may be used.

2) The cash/money that declared as cash waqf should be exchanged with fixed asset such as land or buildings and only its usufruct that might be used.

3) The cash/money itself should be valid unless the cash waqf is not allowed.

Pertaining to the property created as waqf, there are three key restrictions on this matter. Similarly, these restrictions also applied on cash waqf.

1) Irrevocability, means that the founder cannot revoke the money if the money has been already declared as waqf.

2) Perpetually, which means that the money declared as waqf must be perpetual for the purpose of ascertain the regular support to beneficiaries.

3) Inalienability, the money declared as cash waqf is treated like frozen asset, it cannot be subject to a gift, inheritance, or any alienation.

Subsequently, subject to the beneficiaries of cash waqf (almawquf 'alaihim), cash waqf can be distinguished into three types:

1) Waqf khayri (public waqf), the money declared as waqf endowed by the founder for the purposes of general welfare of society, the poor, and the needy people. 
2) Waqf dhurri (family waqf), the money declared as waqf for the purposes to children and grandchildren, relatives, or to any persons specified by the founder.

3) Al-waqf al-mushtarak (combined public and family waqf), amount of money declared as waqf to support both public and his family.

The founder of cash waqf is recommended to incorporate the stipulations in cash-waqf deed, as this will give the trustee the flexibility whenever change happened in the society and whenever its necessary to change the beneficiaries. The stipulations for cash waqf are ziyadah (increase) and nuqsan (decrease), idkal (addition) and ikhraj (removal), l'ta (granting) and hirman (dispossession), taghyir (replacement) and tabdil (conversion), and istibdal (substitution) and ibdal (exchange).

Several benefits from cash waqf can be written as follows:

1) Cash waqf can enhance the different sectors in the Muslim countries. Although the intention of founder of cash waqf is to attain falah, indirectly he also contributes to society through financing the education institution, healthcare, places the poor and the needy. In addition to that, it also can financing the basic infrastructure that is vital for society such as roads, bridges, water supply, etc.

2) Reduction in government expenditure. Through cash waqf, the founder indirectly also help the government by which reduction in the government expenditure which eventually leads to smaller budget deficit and will lower the external borrowing.

3) Reduction of Unemployment. The waqf institution provides a job for people such as job for teachers, team managers, doctors and nurses, professionals, drivers etc. In addition, the investment of cash waqf can finance the projects at which more people can be employed. The revenue generated from cash waqf project also can be utilized for financing small projects where it can provides another job for unemployed as well.

4) Through the creation of cash waqf, enable creation of commercial activities which are needed to develop the economic and improve the wealth of Muslim society. 
5) Creation of interest-free institution that sharia compliance and reduce the riba dealing transactions. In turn, it will give a chance for Muslim society to borrow money from these institutions.

\subsection{Previous Studies on Cash Waqf}

Generally speaking the waqf acceptance among the public are encouraging and it is becoming one of the popular Islamic financial instruments among Muslim and non-Muslim as well. As cited in most literatures had emphasized that waqf is not only focuses on the religiosity point of view but it has great significant input to the ummah development. It has been noted how waqf does contributes to the societal developments and it was known as the Philanthropy of waqf where it is mainly concentrate on public type's infrastructures and developments. For instance, improvement of community in the sense of improving the public utilities, financial assistance to poor to meets their needs and wants, schools, bridge, health check up and many other (Kahf, 2010).

The practices of Waqf can be seen since the era of Prophet Muhammad (pbuh) as cited in Anwar et al. (2014) in the paper where the Prophet Muhammad (pbuh) in Medina when the inflow of immigrant has caused for scares of water supply. This has caused for expensive price of water in Medina. Prophet Muhammad (pbuh) called anyone of his companion to purchase the Bir' Ruma (it is a Ruma well) and declared it for Waqf. Caliph Uthman volunteers himself and buys the well and declares it as Waqf for the Medina societies. This is one of the examples to shows the philanthropy of Waqf that took place in the past.

In addition to that, Cizakca (2000) mentioned that the education industry is one of the most popular Waqf based institution. It means the religiosity itself is not only contributing factor to the Waqf but there are other area as well like education. This has been agreed by Kahf (2010) where the Waqf development can be seen from number of mosque and education centre. For example University of Al- Azhar is one of most prominent university which funded by Waqf at Cairo, Egypt. This has further proven that Waqf is really useful to the poor people to get access to all the facilities available within the country. As noted knowledge is must 
achieve objectives for a Muslim and by Waqf it will helps to produce a number of scholars and educated society which can help to develop and contributes to the Ummah development. Moreover, aside from education, health industry is also part of Waqf development where it will use to funded health services. The coverage would be in the form of construction of hospital building, professional expenses, medicines and many other (Kahf, 2010). One of best examples of Waqf funded hospital is at Istanbul, Shishli Children Hospital where it was founded in 1898 and becoming very popular

Interestingly, Antonio (2002) had justified that there four benefits and advantages in enforcing the cash waqf. Firstly, cash waqf does not require richness in wealth especially to those who are poor, subsequently; everybody in the society also can contribute to cash waqf. Second, waqf via a pool of cash money could generate more funds, which could be used to develop assets such as undeveloped Waqf land and other abandoned land for business and agricultural purposes. In addition to that cash waqf also can use to cover or help institutions who are facing financial problem or liquidity issues to make them survive. Finally, the cash waqf could diminish the reliance of Islamic institutions to the government and they have their own funding institution. by creating cash waqf.

Therefore, the importance of cash waqf is getting popular as it has benefited in many ways. Hence, there are number of research has been conducted where it had focuses on the different aspects of cash waqf development. For example, Islahi (1996) indicates that waqf is very importance and should be internationalize by establishing non - governmental agencies world Muslim institution where it should offer public goods on higher scales and in much more fashionable styles that has been the case up till now in order to overcome the problem related to combat illiteracy, sickness and lack of technical skills. In addition, there is a need to restructure again the current present of cash waqf setup in order to increasing their performance in the form of improving the efficiency and the dynamic management of cash waqf system. This would further increase the economics of scale, objective of innovation and development of cash waqf and consistent with Shariah requirement. However, in the study by Mohsin (2013), it is very 
clear that the potential of cash waqf financing is not affected by the religiosity point of view but also financing different goods and services who needed globally such as education, health and social services. Hence, by focusing other aspects, it will further help to enhance the welfare of society's at large scales. Following the Mohsin (2013) arguments, specifically on education, Aziz (2012) said that the Waqf in education is not a new development in Islam. It has been already taking place in the 17th century where most of the educational activities are funded by Waqf and sadaqah (voluntarily contribution). Hence it can concluded that waqf in education is really needed and have robust impact to the society especially those are not financially strong.

On the other hand, there are some researchers emphasized cash waqf also can be used to help financing enterprises particularly micro enterprises (Cizakca, 2004; Dusuki, 2008). According to these studies, the Waqf can plays a significant role in allocating enough funds to the micro entrepreneurs. This will definitely boost up the economic growth and play a vital role in the socioeconomic development by enabling the participation of micro entrepreneur in the economic activities.

Despite the existing literature that have discussed on the development of cash waqf in the context of worldwide, there is limited research has been carried out in the perspective of Malaysian intention in using cash waqf. In addition, most of the studies have exhaustively covered the waqf development on education, health and religiosity influences as a subject matter to illustrate the concept of cash waqf. With this gap and initiative, the current study has motivated to undertake in-depth analysis on the determinants pertaining to public intention to use cash waqf in the context of Malaysia.

\subsection{Conceptual Framework and Hypothesis}

\subsubsection{Intention}

The words intention has been precisely discuss in the Islam and it is play an important role for human being who are seeking the reward from the Allah (SWT). In the Hadith of Sahih Bukhary (001:001) (as cited by Asmy, 2015), it is clearly stated that: 
"The reward of deeds depends upon the intentions and every person will get rewarded according to what he has intended and a person will get the reward according to his intentions. So whoever emigrated for Allah and his Messenger, then his emigration will be for Allah and his Messenger; and whoever emigrated for worldly benefits or for a woman to marry, his emigration would be for what he emigrated for".

Based on this understanding, it is clear that the Hadith seem to be illustrating the human being voluntary action and there is some kind reason or intention behind it. When the Prophet (pbuh) mentioned that. "...and every man will have only what he intended", he was informing us of the outcome of this in Islamic law. If the man did any good thing with a good intention, then he or she will get reward for what he or she has performed. If it bad, then he/she will be get penalty or punishment.

Given the importance of the intention in Islamic, therefore, the study would like to explore in details in regards public intention in using cash Waqf. This study explicitly will explore the intention in use cash Waqf by looking at the three main important factors, namely (i) Religious obligation, (ii) Social influence and (iii) Attitude.

\subsubsection{Religious Obligation and Intention}

There are many literatures mentioned that religiosity plays an important role in influencing the person intention. This has been supported by many existing studies in the area of Islamic banking and finance. In the study by Erol and Bdour (1989), it is very clear from the findings that religiosity, rate of return and the bank reputation plays an important role in Islamic bank selection in Jordan. Similarly, Metawa and Almossawi (1998), attempted to analyze the selection criteria in choosing Islamic bank using non parametric approach. The selection criteria are consists of rate of return, services, expediency and followed by religion. The results concluded that the most influencing criteria in selecting Islamic banks is religiosity 
However, in other research (Haron, Ahmad, \& Planisek, 1994), in the context of Malaysia, proved that Most Muslim said that the fast and efficient service is the main factor when customers want to choose bank. For non-Muslim: Friendliness of bank personnel to be most considered factors. Author concluded that, Islamic bank should not over emphasize on religion factor as a strategy to attract more customer. This has been agreed by Dusuki and Abdullah (2007), where religion is not really a main reason for public to patronize Islamic banks. follows:

Based on the above literature, the hypothesis would be as

$H_{o}$ : Religious obligation does not significantly influence the intention to use Cash Waqf.

$H_{1}$ : Religious obligation does significantly influence the intention to use Cash Waqf.

\subsubsection{Attitude and Intention}

Existing studies have proved that the attitude factor is really plays important role in intention to use (Lada, Tanakinjal, \& Amin, 2009; Razak \& Abduh, 2012; Amin, Hamid, Lada, \& Anis, 2008; Amin \& Choong, 2011; and Kim, Kim, \& Shin, 2009).

In the study performed by Lada et al. (2009), the results depicted that one of the main factors that attracted the consumer to choose Halal products is attitude. They found that attitude plays an important role in the selection criteria and also significantly and positively related to intention to consumer Halal product. Similarly, Razak and Abduh (2012) found that attitude was significantly and positively influence the customer intention in using Musharakah Mutanaqisah contract. Basically this study was prepared to postulate the intention of consumer in Malaysia to opt for Musharakah Mutanaqisah house financing and the sample size was about 300 respondents.

In addition, by employing SEM in Theory of Reasoned Action (TRA), Amin et.al (2008) attempted to depict the intention of accounting students in choose Islamic accounting course. The result shows that the attitude of the students plays a major role in choosing that particular subject. Similar to Amin et al. (2008), Kim 
et al. (2009) also found the same findings in the context of intention in using mobile technology in United States. To conclude, the results of all the above studies confirmed the relationship between attitude and buyers' intention.

Based on the above literature, the hypothesis would be as follows:

$H_{o}$ : Attitude does not significantly influence the intention to use Cash Waqf.

$H_{1}$ : Attitude does significantly influence the intention to use Cash Waqf.

\subsubsection{Social Influence and Intention}

As per literature, there are many literatures mentioned that the social influences has a significant impact on the intention to use. This has been also evidenced in the previous research (Echchabi \& Olaniyi, 2012; Abduh, Omar, \& Duasa, 2011; Amin and Chong, 2011). In the study by Echchabi and Olaniyi (2012), they have found that the social influence is also one of the factors where positively influencing the customer intention to choose Islamic banking product in Malaysia. In addition, alternatively Abduh et al. (2011), in the context of Indonesia, found that the social influence tends to explain more on why consumer withdraw their fund from Islamic banking in Indonesia followed by attitude factor. Similarly, by using 221 samples of respondent, Amin and Chong (2011), proved that the social influence affects the intention of consumer in choosing Islamic pawnshop.

Therefore, the hypothesis would be as follows:

$H_{o}$ : Social Influence does not significantly influence the intention to use Cash Waqf.

$H_{1}$ : Social Influence does significantly influence the intention to use Cash Waqf.

\subsubsection{Religious Obligation and Social Influences}

Social factor is known as one of the important variables that influencing on people intention to use services. In the context of 
social culture influence and the service, religion is one of the social elements that influence customer intention on using any services. In this case religion acts as a sub - social element on how people are behaving (Sadler, 1970). Religion can influence the society in two sources. First and foremost, religion provides guidelines as well as clear cut that straightforwardly influence the society or individual behaviour (Harrell, Hutt, \& Anderson, 1986). The best example would be the prohibition of using alcohol and for Muslims. Second, as an influential social institution religion has an direct or indirect role in enhancing culture, attitudes and values orientation in society (Al Habshi \& Syed-Agil, 1994).

Hence, the hypothesis would be as follows:

$H_{o}$ : Religious obligation does not significantly contribute to the social influences.

$H_{1}$ : Religious obligation does significantly contribute to the social influences.

\subsubsection{Religious Obligation and Attitude}

By reviewing the literatures on attitudes towards Islamic financial products and services, Gait and Worthington (2009) finalized that the inclination to Islamic methods of finance is subsumed to the criteria taken in taken in choosing a conventional bank. On top of that, Gait and Worthington (2009) had also surveyed about 300 respondents from business firm and found that majority of Libyan business was claimed that Islamic finance is good. The intention factor in preferring Islamic finance would be religion and the attitude of the respondents from business firm.

Therefore, the hypothesis would be as follows:

$H_{o}$ : Religious obligation does not significantly contribute to attitude.

$H_{1}$ : Religious obligation does significantly contribute to the attitude.

\subsubsection{Attitude and Social Influences}

Existing studies have proved that the attitude factor was influenced by social influences (De Mooij, 2004; Hassan \& Hanafi, 2000). It 
means that the attitude of an individual is shaped by the social influences in term of social reflection, acceptance by public etc. De Mooij (2004) revealed that social influence will determine whether customer will choose financial institution. However, the author had also argued that the attitude of customer in Malaysia was different and it will definitely influence the customer intention to choose financial institution due to the social diversity. Similarly, Hassan (2010) explained that the attitude and social influences significantly the intention for higher learning institutions.

The final hypothesis from the above literatures would be as follows:

$H_{o}$ : Attitude obligation does not significantly contribute to social influences.

$H_{1}$ : Attitude obligation does significantly contribute to the social influences.

From the above mentioned studies, the religion itself is not only the factor influencing the public intention in use Cash Waqf. Hence, this study will incorporate all of the above-mentioned attributes in order to present the comprehensive findings that influencing the public intention in using Cash Waqf. This study will employs the Structural Equation Modeling to identify the most influencing variables.

\section{METHODOLOGY}

This research is conducted in the case of Malaysia. The survey questionnaire was self-administered to collect information about the determinant factors that influencing the use of cash Waqf by public. To measuring this information, Likert-scale based questionnaire was developed (1-Strongly Disagree and 5-Strongly Agree). Basically there are about 25 items which belongs to different factors. These item and factors are developing from the existing studies and literatures. The first part of the questionnaire was mainly focuses on demographic profiles of the respondents such as gender, age, marital status, education level, employment level and religion. In addition, the language used in the questionnaire was in English and distributed as such, since in 
Malaysia, English is considered as second language. Moreover, our target group is not only from Muslim, surprisingly non-Muslim is also aware about the cash Waqf. The 25 items are comprises from different factors such as Attitudes, Social influences, Religious obligation, Government support and Intention. However, due to higher multicollinearity issue with government support, this variable has been dropped from this study.

The data collection was made using self-administered questionnaire. The survey was randomly distributed in Klang Valley (Bangsar and Damansara) and Selangor (IIUM and Gombak). In total about 180 surveys but only managed to get about 150 surveys which was properly filled up due to time constraints. The data collection was done mainly during the working hours in order to avoid the potential bias of public concentration on a specific time or days.

Structural Equation Modeling (SEM), AMOS version 18 has been used for analysis purpose and it is a technique for measuring relationships among latent variables. When applying the SEM technique for analytical procedures, many issues are remained. These issues may concern various overall fit indices and the selection of the appropriate approach. There are several indicators of goodness-of-fit and most SEM scholars recommend evaluating the models by observing more than one of these indicators, such as CFI and RMSEA. The main study used SEM because it has two advantages, namely (i) its estimation of multiple and interrelated dependence relationships; and (ii) its ability to represent unobserved concepts in these relationships and account for measurement error in the estimation process.

\section{FINDINGS AND DISCUSSION}

\subsection{Demographics}

To begin with, we present the descriptive statistic of this study. Table 2 summarizes the descriptive of the samples in this study based on gender, age, marital status, educational level, income level, employment, and religion. 
Table 2.

Descriptive Statistics of the samples $(n=114)$

\begin{tabular}{|c|c|c|c|}
\hline & & & Valid Percent (\%) \\
\hline \multirow[t]{2}{*}{1} & Gender & Male & 47.4 \\
\hline & & Female & 52.6 \\
\hline \multirow[t]{4}{*}{2} & Age & $20-30$ years & 41.2 \\
\hline & & $31-40$ years & 44.7 \\
\hline & & $41-50$ years & 10.5 \\
\hline & & $>50$ years & 3.5 \\
\hline \multirow[t]{2}{*}{3} & Marital Status & Single & 40.4 \\
\hline & & Married & 59.6 \\
\hline \multirow[t]{5}{*}{4} & Educational Level & Secondary (SPM) & 10.5 \\
\hline & & Diploma & 32.5 \\
\hline & & Bachelor & 30.7 \\
\hline & & Masters & 14.9 \\
\hline & & $\mathrm{PhD}$ & 11.4 \\
\hline \multirow[t]{5}{*}{5} & Income Level & RM0-1,000 & 12.3 \\
\hline & & RM1,000-3,000 & 42.1 \\
\hline & & RM3,000-5,000 & 30.7 \\
\hline & & RM5,000-10,000 & 9.6 \\
\hline & & $>\mathrm{RM} 10,000$ & 5.3 \\
\hline \multirow[t]{3}{*}{6} & Employment & Government & 41.2 \\
\hline & & Private & 44.7 \\
\hline & & Others & 14 \\
\hline \multirow[t]{5}{*}{7} & Religion & Muslim & 89.5 \\
\hline & & Christian & 2.6 \\
\hline & & Buddhist & 4.4 \\
\hline & & Hindu & 3.5 \\
\hline & & Others & 0 \\
\hline
\end{tabular}

According to the Table 2 above, our samples are predominantly female, accounted for $52.6 \%$ of the respondents. In our cases, the $44.7 \%$ respondents are falls in the range of $31-40$ years old. This percentage appears to be consistent with prior studies, i.e. Metawa and Almossawi (1998) suggest that exploring the perceptions of people and customers within the age 20-50 years group will have more influence on the policies. Hence, this study may provide useful picture on investigating the determinants of public society in Klang Valley to contribute on cash waqf instruments.

The result from descriptive statistics also indicates that our respondents have a good education background, with more than $30 \%$ holding diploma and bachelor degree, and about $14.9 \%$ of 
respondents are master holders. Moreover, in term of monthly income, $42.1 \%$ of our respondents earn between RM1,000 to RM3,000 per month. In the second place, $30.7 \%$ of our respondents falls within the range of RM3,000 to RM5,000 monthly income group. This findings is consistent with the pattern of Malaysian household income distribution in which most of Malaysian earnings between RM1,000 to RM5,000 or middle-income class.

Subsequently, from the Table 2 above, we can also have information that most of our respondents are predominantly worked in the private sector accounted for $44.7 \%$, while about $41.2 \%$ of our respondents are in the government sector. In this study, most of our respondents are Muslim with $89.5 \%$ proportion, while only small fraction of our respondents are Christian, Buddhist, and Hindu. Interestingly, this study also can capture the perception of non-Muslim society that influences them to contribute on cash waqf instruments.

\subsection{Confirmatory Factor Analysis (CFA)}

A Confirmatory Factor Analysis (CFA) of the measurement model addressing the relationship of the observed indicators to the latent constructs with all the constructs be inter-correlated to each other. In that, we tested using AMOS 18.0. Specifically, when we see squared multiple correlation exhibited that all of the measurement items were $>0.5$, which means that a good reliability level. In that, the measurement model of cash waqf contribution have 18 observed indicators to estimate the model fit. Subsequently, we conducted CFA and the results of this measurement exhibited a fit to the sample data. In goodness-of-fit model, the model had CFI of 0.948 which was above the acceptance level and RMSEA of 0.078 which was below the acceptance level and hence regarded as satisfactory. Overall, the values were ranged within the acceptable level and hence they represented an acceptable model fit (see Table 3). 
Table 3.

Fit Indices for Measurement Model

\begin{tabular}{llll}
\hline$X^{2}$ & $\mathrm{df}$ & $\mathrm{CFI}$ & RMSEA \\
\hline 213.389 & 126 & 0.948 & 0.078 \\
\hline
\end{tabular}

\subsection{Convergent and Discriminant Validity}

To checking the reliability of religious obligations (RO), attitude (ATT), social influence (SI), and intention to use cash waqf (ICW), thus construct reliability were calculated. In all cases, the coefficient of construct reliability were greater that the minimum standard of 0.70 , which lead us to gain an insight that they provide a good estimate of internal consistency reliability. Particularly, the coefficient of each construct reliability obtained for RO, ATT, SI, and ICW are 0.914, 0.901, 0,901, and 0.927 respectively, which considerably exceeding the minimum acceptable threshold. Moreover, to determine the convergent validity for each construct, hence we also used standardized factor loadings for each items. Based on the findings, its clearly seen that each factor loadings of cash waqf indicators are exceeding the threshold level of 0.50 . The results indicated that each factor loadings swinging from 0.71 to 0.94 . Since each factor loading on each construct was exceeding 0.50 threshold, thus, the convergent validity for each construct (religious obligation, attitude, social influence, and intention to use cash waqf) was established and provide evidence for construct validity. Aside from that, average variance extracted (AVE) was calculated in order to investigate the discriminant validity for the four constructs. In our findings, the AVE ranged from 0.610 to 0.715 . 
Table 4.

Convergent Validity

\begin{tabular}{lllll}
\hline & RO & ATT & SI & ICW \\
\hline RO1 & 0.71 & & & \\
RO2 & 0.76 & & & \\
RO3 & 0.89 & & & \\
RO4 & 0.91 & & & \\
RO5 & 0.85 & & & \\
\hline ATT1 & & 0.75 & & \\
ATT2 & & 0.94 & & \\
ATT3 & 0.86 & & \\
ATT4 & & 0.77 & & \\
\hline SI1 & & & 0.92 & \\
SI2 & & & 0.84 & 0.72 \\
SI3 & & & 0.67 & \\
SI4 & & & & 0.86 \\
\hline ICWI1 & & & & 0.90 \\
CWI2 & & & 0.89 \\
CWI3 & & & & 0.81 \\
CWI4 & & & & \\
CWI5 & & & & \\
\hline Avg. variance & 0.683 & 0.696 & 0.630 & 0.715 \\
extracted & & \multirow{2}{*}{0.901} & 0.901 & 0.927 \\
\hline Contruct & 0.914 & & & \\
reliability & & & & \\
\hline
\end{tabular}

The idea of discriminant validity is the construct should be different and not be related to each other. According to the table, we provide evidence that the correlation between the two constructs is discriminated from each other. For instance, as we observed that the correlation between $\mathrm{ATT}, \mathrm{RO}=0.554$, correlation between $\mathrm{SI}, \mathrm{RO}=0.482$, and correlation between ICW, $\mathrm{RO}=0.554$. Subsequently, the squared rooted of AVE between each pair factors should be exceeding the correlation estimated between factors; hence the discriminant validity is ratified. In our findings, the value of AVE of each constructs $(0.683,0.696,0.610,0.718$ for RO, ATT, SI, and ICW respectively) are higher than the correlation estimated between factors $(0.554,0.482,0.5,0.325,0.53$, and 0.617$)$. In that, our model can establish discriminant validity. 
Table 5.

Discriminant Validity

\begin{tabular}{lcccc}
\hline & RO & ATT & SI & ICW \\
\hline RO & 1 & & & \\
ATT & $0.554^{* * *}$ & 1 & & \\
SI & $0.482^{* * *}$ & $0.325^{* * *}$ & 1 & \\
ICS & $0.5^{* * *}$ & $0.53^{*}$ & $0.617^{* * *}$ & 1 \\
\hline
\end{tabular}

Notes: below the diagonal level, correlation estimated between the factors.

Having evidence that our model contains both convergent validity and discriminant validity, hence, we can infer that our model can establish a construct validity.

\subsection{Structural Model Testing}

After done with the measurement model validation and in line with the entire requirement such as fit indices, a structural model can used to test using the Structural Equation Modelling (SEM). Basically the purpose of structural theory is to postulates conceptual relationship among the constructs in the model. The final structural model and the single headed arrow are used to test the causal effects as shown in Figure 2.

\section{Validation of the Structural Model}

Validity of the structural model can take place as follows;

i) Fit indices: $\chi^{2}, \mathrm{CFI}, \mathrm{RMSEA}$.

ii) Factor loadings obtained from measurement model and fullfledged model should be very close.

iii) Test the significance of the path coefficients. Correlations between constructs in the measurement model and path coefficients in the structural model should be comparable.

The fit indices will be used to see the goodness-of-fit test. Intention to use Cash Waqf (ICW) is known as dependent variable (construct), with which all independent variables (constructs), namely, religious obligation, social influences and attitude. The final results of the model fit indices as follows: 
Table 6.

Fit Indices for Structural Model

\begin{tabular}{llll}
\hline$\chi^{2}$ & df & CFI & RMSEA \\
\hline 211.917 & 125 & 0.948 & 0.078 \\
\hline
\end{tabular}

The fit indices can be verified from CFI and RMSEA with respectively values of $0.927(>0.90)$ and $0.078(<0.08)$. The statistics are same as those of the best-fit measurement model used for structural model. On top of that, factor loading for both measurement model and structural model are equally same and it indicates further valid the model (See Table 7). The values of factor are almost equal and the model is fit based on this information.

In addition, the correlations between the constructs in the measurement model and path coefficient are totally comparable and this has further validated the data where it is fit enough for the structural analysis (See Table 8).

Table 7.

Factor Loading from Measurement and Structural Model

\begin{tabular}{llcc}
\hline \multicolumn{1}{c}{ Indicator } & \multicolumn{1}{c}{ Construct } & $\begin{array}{c}\text { Measurement } \\
\text { model }\end{array}$ & $\begin{array}{c}\text { Structural } \\
\text { model }\end{array}$ \\
\hline ICW1 & ICW & 0.76 & 0.76 \\
ICW2 & ICW & 0.86 & 0.86 \\
ICW3 & ICW & 0.90 & 0.90 \\
ICW4 & ICW & 0.89 & 0.89 \\
ICW5 & ICW & 0.81 & 0.81 \\
RO1 & Religious Obligation & 0.71 & 0.71 \\
RO2 & Religious Obligation & 0.76 & 0.76 \\
RO3 & Religious Obligation & 0.89 & 0.89 \\
RO4 & Religious Obligation & 0.91 & 0.91 \\
RO5 & Religious Obligation & 0.85 & 0.85 \\
ATT1 & Attitude & 0.75 & 0.75 \\
ATT2 & Attitude & 0.94 & 0.94 \\
ATT3 & Attitude & 0.86 & 0.86 \\
ATT4 & Attitude & 0.77 & 0.77 \\
SI1 & Social Influence & 0.92 & 0.86 \\
SI2 & Social Influence & 0.84 & 0.78 \\
SI3 & Social Influence & 0.72 & 0.76 \\
SI4 & Social Influence & 0.67 & 0.71 \\
\hline
\end{tabular}

Source: SEM result 
Table 8.

Correlation and Parameter Estimate for Measurement and Structural Model

\begin{tabular}{lclc}
\hline \multicolumn{2}{c}{ Measurement Model } & \multicolumn{2}{c}{ Structural Model } \\
\hline \multicolumn{1}{c}{ Relationship } & $\begin{array}{c}\text { Parameter } \\
\text { estimate }\end{array}$ & Relationship & $\begin{array}{c}\text { Parameter } \\
\text { estimate }\end{array}$ \\
\hline RO correlates ICW & 0.50 & $\mathrm{H}_{1}: \mathrm{RO} \rightarrow \mathrm{ICW}$ & 0.0700 \\
SI correlates ICW & 0.62 & $\mathrm{H}_{2}: \mathrm{A} \rightarrow \mathrm{ICW}$ & 0.3100 \\
AT correlates ICW & 0.53 & $\mathrm{H}_{3}: \mathrm{SI} \rightarrow \mathrm{ICW}$ & 0.4900 \\
RO correlates SI & 0.48 & $\mathrm{H}_{4}: \mathrm{RO} \rightarrow \mathrm{SI}$ & 0.4700 \\
RO correlates AT & 0.55 & $\mathrm{H}_{5}: \mathrm{RO} \rightarrow \mathrm{AT}$ & -0.550 \\
SI correlates AT & 0.32 & $\mathrm{H}_{6}: \mathrm{A} \rightarrow \mathrm{SI}$ & 0.1200 \\
\hline Notes: & & \\
ICW: Intention to use Cash Waqf & & \\
Religious Obligation: RO & & & \\
Social Influence: SI & & & \\
Attitude: AT & & & \\
\hline
\end{tabular}

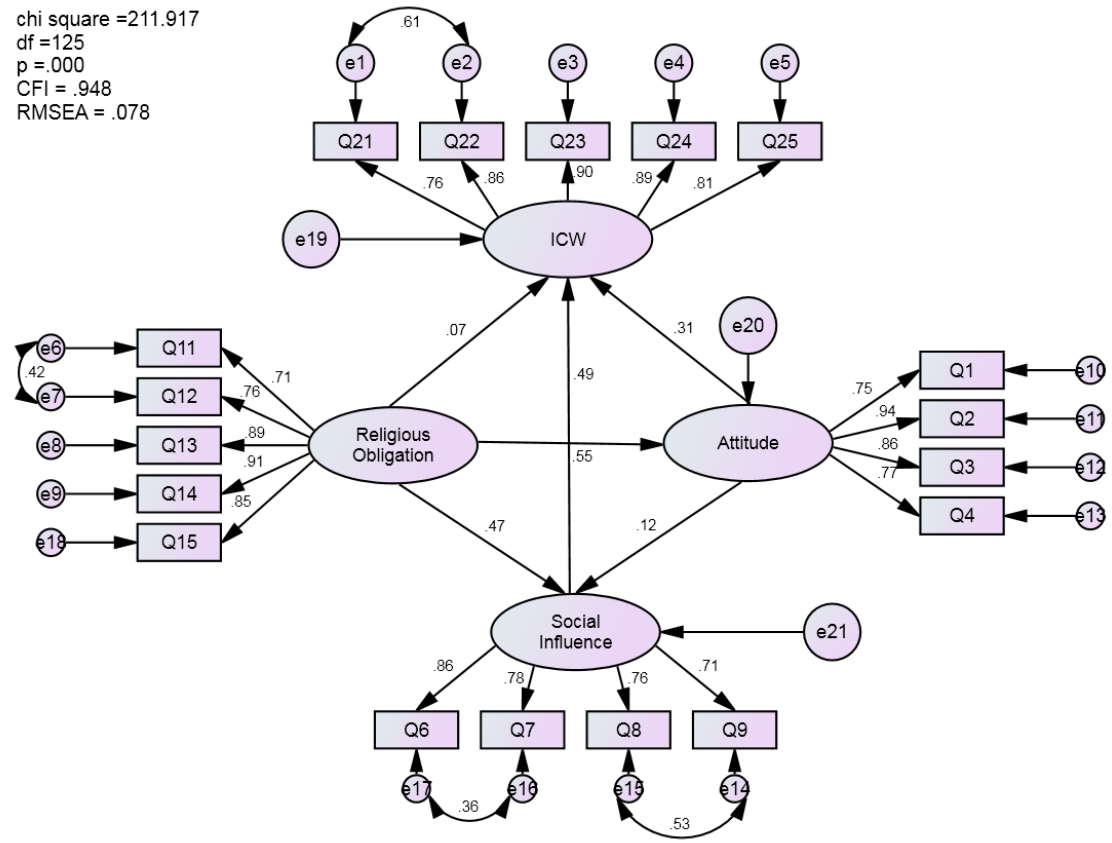

Figure 2.

Structural Model's of Cash Waqf Contributions 


\subsection{Result of Hypotheses Testing}

In total there are six main hypotheses were developed in this study and these hypotheses are examined by focus at the significance level, signs and the standardized estimated regression weights (Hair, Black, Babin, \& Anderson, 2010).

\subsubsection{Discussion of Hypothesis 1}

$H_{1}$ : Religious obligation does significantly influence the intention to use Cash Waqf.

Table 9.

Test's Result of Hypothesis 1

\begin{tabular}{llllll}
\hline Hypothesized Path & $\begin{array}{l}\text { Standardized } \\
\text { Coefficient }\end{array}$ & CR & p-Value & Decision \\
\hline$H_{1} \quad$ RO $\rightarrow \mathrm{ICW}$ & .071 & .650 & .516 & $\begin{array}{l}\text { RO does not } \\
\text { significantly } \\
\text { influence the ICW }\end{array}$ \\
\hline *p-value $<0.05$ & & & &
\end{tabular}

Note:

$H_{0}$ : Religious obligation does not significantly (positively) influence the intention of using the Cash Waqf.

The result of above table indicates that the religious obligation towards the intention of using Cash Waqf is statistically not significant $(\beta 1=0.071, t$-value $=0.650, p>0.05)$ and accepting the null hypothesis. This is consistent with the previous study that has been conducted (Haron et al. 1994; Dusuki \& Abdullah, 2007) where both of this paper, concluded that there are other factors that normally customer do take into account rather than religious factor in making decision.

Therefore, it is very important for the Waqf institution to provide religious awareness to the public in regards the importance of Waqf. This can be done via the mass media as suggested by Asmy (2015) by utilising mass media for instance television, radio and news paper or Facebook to provide religious type of discussion in regards Waqf. It is expected by doing this; it will definitely increase their intention to use Cash Waqf. 


\subsubsection{Discussion of Hypothesis 2}

$H_{1}$ : Attitude does significantly influence the intention to use Cash Waqf.

Table 10.

Test's Result of Hypothesis 2

\begin{tabular}{lllll}
\hline Hypothesized Path & $\begin{array}{l}\text { Standardized } \\
\text { Coefficient }\end{array}$ & CR & p-Value & Decision \\
\hline$H_{1} \quad$ AT $\rightarrow$ ICW & .536 & 4.089 & 0.000 & $\begin{array}{l}\text { AT does } \\
\text { significantly } \\
\text { influence the ICW }\end{array}$ \\
\hline${ }^{*}$ p-value $<0.05$ & & & & \\
\hline
\end{tabular}

Note:

$H_{0}$ : Attitude does not significantly influence the intention to use Cash Waqt.

As shown in the above table, attitude influence towards the intention to use Cash Waqf is statistically significant ( $\beta 1=0.536, \mathrm{t}$ value $=4.089, p<0.05$ ) and rejecting the null hypothesis. In other words, When Attitude goes up by 1 standard deviation, ICW goes up by 0.307 standard deviations. The previous studies is also depicted the same relationship as this research such as Lada et al. (2009), Razak and Abduh (2012), and Amin et al. (2008) found that the attitude playing an important role in intention. Therefore, it is highly recommended to the Waqf institution to come out with a comprehensive plan in order to attract the more people to use Cash Waqf and build a positive image Cash Waqf by letting the public know about it. This can be done via good marketing strategy and awareness campaign especially to the youngster and senior citizen.

\subsubsection{Discussion of Hypothesis 3}

$H_{1}$ : Social Influence does significantly influence the intention to use Cash Waqf.

Table 11.

Test's Result of Hypothesis 3

\begin{tabular}{llllll}
\hline Hypothesized Path & $\begin{array}{l}\text { Standardized } \\
\text { Coefficient }\end{array}$ & CR & p-Value & Decision \\
\hline$H_{1}$ & $\mathrm{SI} \rightarrow \mathrm{ICW}$ & .486 & 4.089 & 0.000 & $\begin{array}{l}\text { SI does } \\
\text { significantly } \\
\text { influence the ICW }\end{array}$ \\
\hline
\end{tabular}

*p-value $<0.05$ 
Note:

$H_{0}$ : Social Influence does not significantly influence the intention to use Cash Waqf.

Based on the above table, the social influence on intention to use Cash Waqf is statistically significant $(\beta 1=0.486, C R=4.089$, $\mathrm{p}<0.05)$ and rejecting the null hypothesis. It is very clear that when social influence goes up by 1 standard deviation, ICW goes up by 0.486 standard deviations. The previous studies also revealed the similar finding where the social influences may impact positively on the intention and it had strong relationship (Echchabi \& Olaniyi, 2012; Abduh et al., 2011; Amin \& Chong, 2011). Since the social influence has direct relationship with the intention, the Waqf institution need to play an important role in developing a new method in disseminating all those information related to the Cash Waqf the society using direct or indirect strategy. The social group is also cover all including friends, family member, relatives etc.

\subsubsection{Discussion of Hypothesis 4}

$H_{1}$ : Religious obligation does significantly contribute to the social influences.

Table 12.

Test's Result of Hypothesis 4

\begin{tabular}{lllll}
\hline Hypothesized Path & $\begin{array}{l}\text { Standardized } \\
\text { Coefficient }\end{array}$ & CR & p-Value & Decision \\
\hline$H_{1} \quad \mathrm{RO} \rightarrow \mathrm{SI}$ & .468 & 3.633 & 0.000 & $\begin{array}{l}\text { RO does } \\
\text { significantly } \\
\text { influence the SI }\end{array}$ \\
\hline${ }^{*} \mathrm{p}$-value $<0.05$ & & & & \\
\hline
\end{tabular}

Note:

$H_{0}$ : Religious obligation does not significantly contribute to the social influences.

From the table, it is noted that religious obligation statistically significant $(\beta 1=0.468, C R$ value $=3.633, p<0.05)$ in contributes to the social influences and subsequently influences the intention. Therefore, the null hypothesis is rejected in this case. From SEM result, it can be clearly seen that when religious goes up by 1 standard deviation, social influences goes up by 0.468 standard deviation. The previous study had also postulated that the element of religiosity playing an important role in enhancing the behaviour 
and culture of the society. Highly religious society will lead to better Ummah and follows the stated rules in Islam such as Sadaqah, Zakat and Waqf (Al Habshi \& Syed-Agil, 1994).

\subsubsection{Discussion of Hypothesis 5}

$H_{1}$ : Religious obligation does significantly contribute to attitude.

Table 13.

Test's Result of Hypothesis 5

\begin{tabular}{lllll}
\hline Hypothesized Path & $\begin{array}{l}\text { Standardized } \\
\text { Coefficient }\end{array}$ & CR & p-Value & Decision \\
\hline$H_{1} \quad$ RO $\rightarrow$ AT & .554 & 5.500 & 0.000 & $\begin{array}{l}\text { RO does } \\
\text { significantly } \\
\text { influence the AT }\end{array}$ \\
\hline *p-value $<0.05$ & & & & \\
\hline
\end{tabular}

Note:

$H_{0}$ : Religious obligation does not significantly contribute to the attitude.

In this case, religion is also influencing the attitude of an individual and it can seen from the table above where it is statistically significant $(\beta 1=0.554, C R$ value $=5.500, p<0.05)$ and therefore, rejecting the null hypothesis. The above result is also indicates that when religious obligation goes up by 1 standard deviation, attitude positively goes up by 0.554 standard deviations. Basically, it other words religion will definitely improve the attitude of an individual in performing good deeds and shows good attitude. Religious people normally will have intention and obligation perform prayer, and engage in social type of activities such as charity as directed by their religion (Morgan \& Lawton, 1996).

\subsubsection{Discussion of Hypothesis 6}

$H_{1}$ : Attitude does significantly contribute to social influences.

Table 14.

Test's Result of Hypothesis 6

\begin{tabular}{cclccl}
\hline Hypothesized Path & $\begin{array}{l}\text { Standardized } \\
\text { Coefficient }\end{array}$ & CR & p-Value & Decision \\
\hline$H_{1} \quad$ AT $\rightarrow$ SI & .117 & 0.999 & 0.318 & $\begin{array}{l}\text { AT does not } \\
\text { significantly } \\
\text { influence the SI }\end{array}$ \\
\hline *p-value $<0.05$ & & & \\
\hline
\end{tabular}


Note:

$H_{0}$ : Attitude does not significantly contribute to social influences.

In this case, the table shows that attitude does not statistically significant in contributing to the social influences $(\beta 1=0.117, C R$ value $=0.999, p>0.05)$. Hence it can be concluded that the null hypothesis is failed to be rejected. However, by looking at the existing studies, there is clear picture where attitude of an individual is envisaged by the social influences (Hassan \& Hanafi, 2000). Ironically, in this study, the finding indicates that the attitude does not significantly persuade the social influences.

\section{CONCLUSION AND RECOMMENDATIONS}

\subsection{Conclusion and Recommendations}

The main objective of this research is to investigate the factors which public society perceived as imperative to their participation on cash waqf instruments in Klang Valley and Selangor. The interesting finding of the study is that the religious-obligations is not significantly affect the cash waqf contribution. The religious obligations factor includes 'consistency with sharia principles', "Islamic philosophy', 'Islamic sources: Quran and Hadith', unriba instruments', and 'free from gharar'. Hence, it is very important for the Waqf institution to provide religious awareness to the public in regards the importance of Waqf. This can be done via the mass media by utilising mass media for instance television, radio and news paper or Facebook to provide religious type of discussion in regards Waqf. More so, all Islamic financial institutions should demonstrate their commitment to religiosity program if they want to be perceived as religious-based institutions.

Subsequently, both attitude and social influence are significantly influence the use of cash waqf. It is highly recommended to the Waqf institution to come out with a comprehensive plan in order to attract the more people to use Cash Waqf and build a positive image Cash Waqf by letting the public know about it. This can be done via good marketing strategy and awareness campaign especially to the youngster and senior citizen. 
Aside from that, since the social influence has direct relationship with the intention, the Waqf institution need to play an important role in developing a new method in disseminating all those information related to the Cash Waqf the society using direct or indirect strategy. The social group is also cover all including friends, family member, relatives etc.

\subsection{Limitation and Further Research}

However, there are a few limitations of the current study. The theme of factors that has been applied in this research generated and used in this study are constantly in flux. There are other factors that might be affecting the use of cash Waqf. Thus, there is a need to further examination of other factor that can influence the use of cash Waqf. In addition, the number of sample size can be questionable because in this research due to time constraints, the researchers managed to survey about 114 questionnaires. This may affect the research findings in one way and another. Due to the multicollinearity issues, variable called government support has to be dropped unfortunately, but logically speaking the role of government is really important and needed in promoting cash Waqf. Therefore, it does not mean that by dropping this variable from the research implies that the role of government is not important.

Future research is nevertheless still required that incorporate qualitative means of testing and measuring the factors that influencing the usage of cash Waqf. This will provide more reliable and comprehensive results. Apart from that, an appropriate number of sample size should be incorporated in the research to further validate the results or findings and also use of more sophisticated analysis such as Analytic Network Process (ANP) and Analytic Hierarchy Process (AHP) would be able to further furnish the results. 


\section{REFERENCES}

Abduh, M., Omar, M.A., \& Duasa, J. (2011). Factor influence depositor's withdrawal behaviour in Islamic banking: A theory of reasoned action. World Academy of Science, Engineering and Technology, 5(12), 1813-1818.

Al Habshi, S.O. \& Syed-Agil, S.O. (1994). The role and influence of religion in society. Kuala Lumpur: Institute of Islamic Understanding Malaysia.

Al-Zuhaili. (1989). Usul al-Fiqh al-Islami (v.2) (pp.1020-1025). Damsyik: Dar al-Fiqr.

Amin, H. \& Chong, R. (2011). Determinants for ar-rahnu usage intentions: An empirical investigation. African Journal of Business Management, 5(20), 8181-8191.

Amin, H., Hamid, M.R.A., Lada, S., \& Anis, Z. (2008). The adoption of mobile banking in Malaysia: The case of Bank Islam Malaysia Berhad (BIMB). International Journal of Business and Society, 9(2), 69-86.

Antonio, M.S. (2002). Cash waqf dan anggaran pendidikan umat. Republika.

Anwar, A.P., Meera, A.K., \& Saleem, M.Y. (2014). Priority of waqf development among malaysia cash waqf donors: An AHP approach. Journal of Islamic Finance, 3(1), 013-022.

Asmy, M. (2015). A proposed integrated cash waqf micro enterprise investment (ICWME-I) model for mitigating the financial and human capital development challenges of micro enterprises in Malaysia (Unpublished manuscript).

Aziz, M.R.A. (2012). Introduction to Islamic institutions in economics and finance. Bandar Baru Nilai: USIM Publisher.

Baharuddin, S. (2011). Isu-isu semasa mengenai waqat. Shah Alam: Pusat Penerbitan Universiti (UPENA).

Cizakca, M. (2000). A history of philanthropic foundations: The Islamic world from the seventh century to the present (pp. 210). Istanbul: Bogazici University Press. 
Cizakca, M. (2004). Ottoman cash waqfs revisited: The case of Bursa 1555-1823. Manchester: Foundation for Science Technology and Civilisation.

Dusuki, A.W., \& Abdullah, N.I. (2007). Maqasid al-shari'ah, maslahah and corporate social responsibility. The American Journal of Islamic Social Sciences (AJISS), 24(1), 25-45.

Dusuki, A.W., (2008). Banking for the poor: The role of Islamic banking in microfinance initiatives. Humanomics, 24(1), 9-66.

De Mooij, M. 2004. Consumer behaviour and culture: Consequences for global marketing and advertising. Thousand Oaks, CA: Sage.

Echchabi, A. \& Olaniyi, O.N. (2012). Using theory of reasoned action to model the patronisation behaviour of Islamic banks' customers in Malaysia. Research Journal of Business Management, 6(3), 70-82.

Erol, C. \& El-Bdour, R. (1989). Attitudes, behaviour and patronage factors of bank customers towards Islamic banks. International Journal of Bank Marketing, 7(6), 31-37.

El-Gari, M.A. (2004, March). The Qard hassan bank. Paper presented in The International Seminar on Nonbank Financial Institutions: Islamic Alternatives, jointly organized by Islamic Research and Training Institute, Islamic Development Bank and Islamic Banking and Finance Institute Malaysia, Kuala Lumpur, 1-3 March 2004.

Gait, A. \& Worthington, A. (2009). Libyan business firm attitude towards Islamic methods of finance. Social Science Research Network [Online]. Retrieved from http://ssrn.com/abstract= 1370752

Hair, J.F., Black, W.C., Babin, B.J., \& Anderson, R.E. (2010). Multivariate data analysis $\left(7^{\text {th }}\right.$ ed.). Upper Saddle River, NJ: PrenticeHall.

Harrell, G.D., Hutt, M.D., \& Anderson, J.C. (1986). Path analysis of buyer behaviour under conditions of crowding. Journal of Marketing Research, 17(1), 45-51. 
142 Determinants of Cash Waqf Contribution in Klang Valley and Selangor: A SEM Approach

Haron, S., Ahmad, N., \& Planisek, L. (1994). Bank patronage factors of muslim and non-muslim customers. International Journal of Bank Marketing, 12(1), 32-40.

Hassan, S. \& Hanafi, S. (2000). Iranian Medical Students' Attitudes towards English Language Learning. International Research Journal of Applied and Basic Sciences, 4(12), 3816-3823.

Hassan, M.K. (2010). An integrated poverty alleviation model combi-ning zakat, awqaf and micro-finance. Proceedings of Seventh International Conference-The Tawhidi Epistemology: Zakat and Waqf Economy (pp. 261-281), Bangi, Malaysia.

Islahi, A.A. (1996). provision of public goods - role of voluntary (waqf) sector in Islamic history. In M.A. Mannan (Ed.), Financing Development in Islamic Economics (pp. 367-391). Jeddah: IRTI/IDB.

Kahf, M. (2010). The role of waqf in sustainable development of the ummah. Sustainable development in the light of maqasid al shari'ah (p. 3). Kedah.

Kim, H.B., Kim, T., \& Shin, S.W. (2009). Modelling roles of subjective norms and e-trust in customers' acceptance of airline B2C e-commerce websites. Tourism Management, 30, 266-277.

Lada, S., Tanakinjal, G.H., \& Amin, H. (2009). Predicting intention to choose halal products using theory of reasoned action. International Journal of Islamic and Middle Eastern Finance and Management, 2(1), 66-76.

Mohsin, M.I.A. (2009). Family waqf: Its origin, law prospects. Proceedings of International Conference on Waqf Laws and Management: Reality and Prospects (pp. 3-6).

Mohsin, M.I.A. (2013). Financing through cash-waqf: A revitalization to finance different needs. International Journal of Islamic and Middle Eastern Finance and Management, 6(4), 304-321.

Metawa, A.S. \& Almossawi, M. (1998). Banking behavior of Islamic bank customers: Perspectives and implications. International Journal of Bank Marketing, 16(7), 299-313. 
Morgan, P. \& Lawton, C. (1996). Ethical issues in six religious traditions. Edinburgh: Edinburgh University Press.

Perbadanan Waqf Selangor (MAIS). Retrieved April 3, 2015, from http://www.wakafselangor.gov.my/

Razak, D. A. \& Abduh, M. (2012). Customers attitude towards diminishing partnership home financing in Islamic banking. American Journal of Applied Sciences, 9(4), 593-599.

Sadler, W. (1970). Personality and religion: The role of religion in personality development. London: SCM Press Ltd.

Sayin, B. (1994). Sistem pentadbiran wakaf negeri-negeri di Semenanjung Malaysia: Satu kajian (Master Thesis). Faculty of Islamic Studies, National University of Malaysia, Selangor. 
144 Determinants of Cash Waqf Contribution in Klang Valley and Selangor: A SEM Approach

This page is intentionally left blank 